\title{
ZAGOSPODAROWANIE POWIATU SOKÓLSKIEGO DLA TURYSTYKI ROWEROWEJ
}

\section{Wprowadzenie}

Artykuł powstał na podstawie pracy licencjackiej pod tytułem „Zagospodarowanie powiatu sokólskiego dla turystyki rowerowej", napisanej w 2020 r. pod kierunkiem dr Krzysztofa Piotrowskiego na Wydziale Nauk Geograficznych i Geologicznych Uniwersytetu im. Adama Mickiewicza w Poznaniu.

Turystyka rowerowa staje się coraz bardziej popularną formą spędzania wolnego czasu. W Internecie pojawiają się kolejne blogi, artykuły oraz filmy promujące ten rodzaj aktywności. Turyści rowerowi poszukują informacji, map terenu, przewodników oraz bazy noclegowej i gastronomicznej. Na przestrzeni ostatnich dwudziestu lat można zaobserwować $\mathrm{w}$ naszym kraju rosnące zainteresowanie rowerem i turystyką. Sprzyja temu popularyzacja aktywności fizycznej, promowanie zdrowego trybu życia oraz coraz szersza oferta na rynku rowerowym. Tę sytuację dostrzegają lokalne samorządy, widząc szansę rozwoju dla swojego regionu. Próbują łączyć turystykę rowerową z turystyką kulinarną, kulturową czy innymi popularnymi atrakcjami.

Obszar powiatu sokólskiego jest opisywany jako teren atrakcyjny turystycznie (Wiśniewska, Pluta, Wiśniewski, Nowakowska, 2018). Jednym z powodów jest kuchnia regionalna, charakteryzująca się rozmaitością i bogactwem produktów, ale również prostotą wykonania. Różnorodność kuchni wynika z historii obszaru, który był zamieszkiwany przez kilka różnych grup etnicznych i religijnych. Na badanym obszarze odnajdujemy wpływy ruskie, litewskie, tatarskie, polskie i żydowskie. Dużą atrakcją są skanseny oraz miejsca związane z kultem religijnym 
i sztuką ludową. Ze względu na dużą ilość obszarów zielonych oraz położenie na terenie Zielonych Płuc Polski powiat sokólski jest również interesujący pod względem wypoczynkowym.

\section{Metodyka i źródła danych}

Celem badań było zaproponowanie zmian w zagospodarowaniu powiatu sokólskiego dla turystyki rowerowej na podstawie danych uzyskanych na przełomie 2019 i $2020 \mathrm{r}$.

Pierwszym zadaniem badawczym wykonanym dla osiągnięcia celu pracy było zebranie informacji dotyczących przebiegu tras rowerowych na analizowanym obszarze. Uzyskane dane pomogły w opracowaniu mapy, przedstawiającej rozłożenie tras w powiecie sokólskim. Użyto metod kartograficznych, których celem było przedstawienie na mapie istniejących tras rowerowych, ustalenie w pobliżu której z miejscowości powiatu znajduje się ich najwięcej oraz szczegółowe pokazanie przebiegu tras.

W dniach 10-16.06.2019 r. przeprowadzono rekonesans terenowy, w ramach którego odwiedzono atrakcje turystyczne obszaru badań, zapoznano się ze strukturą sieci tras rowerowych oraz infrastrukturą noclegową i gastronomiczną. $W$ ramach rekonesansu przejechano m.in. cały Rowerowy Szlak Tatarski, zwiedzono meczety w Bohonikach i Kruszynianach. W Sokółce zapoznano się z wystawą w Muzeum Ziemi Sokólskiej, poświęconą kulturze tatarskiej. Kolejnym przystankiem była Suchowola, gdzie udano się do Centrum Trzech Kultur. W celu sprawdzenia możliwości połączenia tras rowerowych powiatu sokólskiego z trasami powiatu augustowskiego, podczas ostatnich dwóch dni rekonesansu terenowego, udano się do Augustowa, gdzie zapoznano się z istniejącą siecią szlaków rowerowych oraz infrastrukturą rowerową w pobliżu przystani.

Na podstawie informacji dostępnych na stronach gmin należących do powiatu, danych zebranych podczas rekonesansu terenowego oraz analizy wcześniej zebranych dokumentów, takich jak mapy i foldery, przeprowadzono analizę SWOT powiatu sokólskiego pod względem możliwości rozwoju turystyki rowerowej.

Ostatnim etapem pracy było zaproponowanie zmian, które lokalne władze mogłyby wprowadzić, aby umożliwić dynamiczny rozwój turystyki rowerowej na badanym obszarze. 


\section{Problem turystyki rowerowej w literaturze}

Na temat turystyki rowerowej powstało wiele artykułów o charakterze naukowym oraz popularnonaukowym. Publikacja, która dostarcza dużo informacji na temat omawianego zagadnienia, jest praca wydana pod patronatem Polskiego Towarzystwa Turystyczno-Krajoznawczego, pod tytułem Turystyka rowerowa w zjednoczonej Europie (Nowacki, Tanaś, 2012). Składa się ona z ponad 20 artykułów, których tematem jest szeroko pojęta turystyka rowerowa i infrastruktura z nią związana. Opracowanie, pomimo tego, że zawiera wiele wartościowych i pomocnych informacji dla rowerzystów, ukazało się kilka lat temu. Od tego czasu turystyka rowerowa stała się bardziej popularna, utworzono również wiele nowych szlaków rowerowych. W latach 2019-2020 można zauważyć niewielką ilość wydawnictw o charakterze naukowym, poruszających omawiane zagadnienie.

Temat turystyki rowerowej i jej rozwoju jest poruszany również w książkach podróżniczych oraz czasopismach branżowych. Magazyny turystyki rowerowej, takie jak Rowertour, przedstawiają różnego rodzaju szlaki rowerowe w Polsce, opisują infrastrukturę turystyczną miast czy popularyzują organizację rajdów rowerowych. Powieści, w których opisywane są wycieczki rowerowe to również ważna część publikacji, bowiem turyści często czerpią z nich inspiracje do nowych wypraw. Możemy znaleźć także publikacje na temat coraz śmielszych podróży rowerowych, jedną z nich jest Po Bajkale Rybickiego (2015), w której opisano wyprawę rowerową po zamarzniętym jeziorze. Sama trasa wynosiła $900 \mathrm{~km}$, a dodatkowo przebiegała w skrajnie nieprzyjaznych dla człowieka warunkach.

O powiecie sokólskim w literaturze pisze się niewiele, najwięcej informacji na temat tego obszaru można znaleźć w Internecie oraz w centrach informacji turystycznej miast powiatu sokólskiego. Trasy rowerowe, zabytki Sokólszczyzny, obiekty agroturystyczne oraz historia miast należących do powiatu zostały przedstawione w publikacji Sokólszczyzna - mini-przewodnik (Wiśniewska, Pluta, Wiśniewski, Nowakowska, 2018).

\section{Charakterystyka obszaru badań}

Powiat sokólski znajduje się na terenie województwa podlaskiego, przy granicy z Białorusią. W granicach powiatu znajduje się 10 gmin, z których największe to: Suchowola, Dąbrowa Białostocka oraz Sokółka. Obszar powiatu znajduje się na terenie Zielonych Płuc Polski, co oznacza, że 
tamtejsze miejscowości wyróżniają się spokojem i cisza, równomierną siecią osadniczą oraz różnorodnością systemu przyrodniczego (Ostrowska, 2020).

Jednym z walorów przyrodniczych powiatu są Wzgórza Sokólskie, zaliczane do obszaru chronionego krajobrazu (rys. 1), a najwyższym wzniesieniem jest Góra Wojnowska (239,5 m n.p.m.). Na terenie powiatu znajduje się wiele dolin rzecznych, zagłębień wytopiskowych oraz różnorodnych form rzeźby terenu. W celu ochrony tych cennych obszarów powstał Park Krajobrazowy Puszczy Knyszyńskiej im. prof. Witolda Sławińskiego (Sokółka.pl, 2020).

Na obszarze powiatu znajduje się sześć form ochrony przyrody. Największym obszarem chronionym jest Biebrzański Park Narodowy, którego

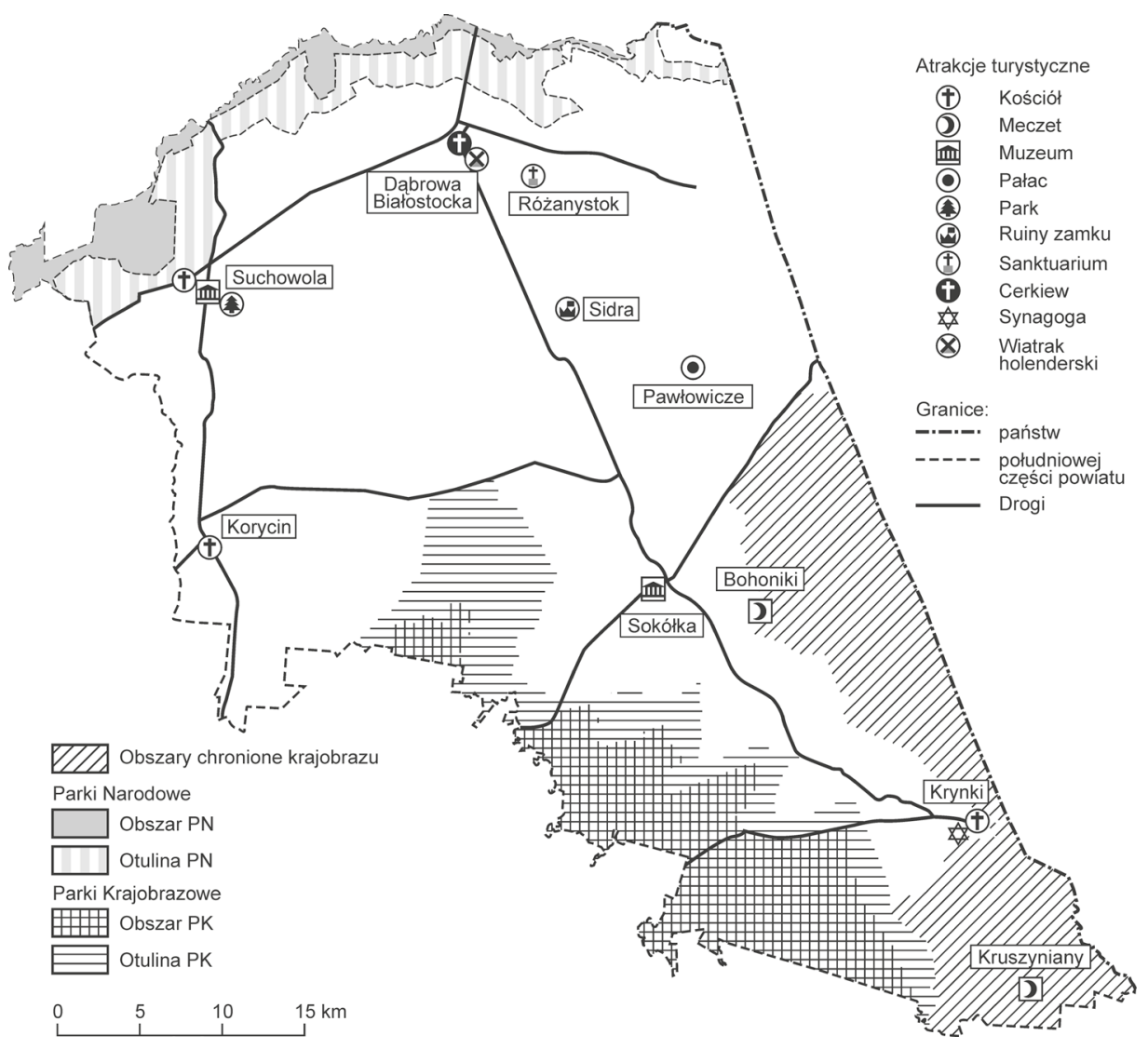

Rysunek 1 . Wybrane formy ochrony przyrody oraz atrakcje turystyczne w powiecie sokólskim

Źródło: opracowanie własne 
fragment przebiega przez gminy: Nowy Dwór, Suchowola i Dąbrowa Białostocka. Jest to największy park narodowy na terenie Polski, jego ważnym zasobem jest rzeka Biebrza wraz z Bagnami Biebrzańskimi (Serwis Informacyjny Powiatu Sokólskiego, 2020).

Na terenie powiatu znajduje się wiele miejscowości posiadających obiekty, które mogą być przedmiotem zainteresowania turystów (rys. 1).

Punktem, w którym rozpoczyna się kilka szlaków rowerowych w mieście, jest Muzeum Ziemi Sokólskiej. Oferuje ono zwiedzającym trzy różne wystawy: pierwsza poświęcona jest historii miasta, druga to ekspozycja na temat Tatarów - ich życia i religii, a trzecia, przypominająca wystrojem izbę wiejska, prezentuje tradycyjne rzeczy pochodzące z regionu miasta (Wiśniewska, Pluta, Wiśniewski, Nowakowska, 2018).

Miejscowościa, w której również można odnaleźć informacje na temat życia Tatarów na podlaskich ziemiach jest Suchowola. W centrum miasta znajduje się kościół pw. św. Piotra i Pawła. Parafia suchowolska jest powiązana z bł. ks. Jerzym Popiełuszka, dzięki czemu otrzymała fragment relikwii, który aktualnie znajduje się w specjalnym relikwiarzu szafkowym w kościele. W Suchowoli zlokalizowany jest również geograficzny środek Europy (Wiśniewska, Pluta, Wiśniewski, Nowakowska, 2018).

Na terenie powiatu sokólskiego znajdują się dwa drewniane meczety, jeden jest położony we wsi Bohoniki, a drugi we wsi Kruszyniany. W 2012 r. obie świątynie zostały wpisane na listę Pomników Historii Polski (Wiśniewska, Pluta, Wiśniewski, Nowakowska, 2018).

Miejscowością znaną z kultu religijnego jest Różanystok. Znajduje się tam Sanktuarium Matki Bożej Różanostockiej z cudownym obrazem Matki Bożej Różanostockiej. Aktualnie w sanktuarium można oglądać nową wersję obrazu, powstałą w $1929 \mathrm{r}$. Na terenie miasta jest również dawny klasztor dominikanów, jeden z niewielu ośrodków o kształcie bryły wzorowanej na barokowych pałacach i późnobarokowym stylu (Wiśniewska, Pluta, Wiśniewski, Nowakowska, 2018).

\section{Infrastruktura turystyczna w powiecie sokólskim}

Na obszarze gminy Sokółka, podobnie jak w gminach Suchowola czy Dąbrowa Białostocka, można zauważyć brak zwartej zabudowy domków i ośrodków wypoczynkowych - sprawia to, że teren nie jest wykorzystywany w celach turystycznych.

Według danych z 2019 r. opublikowanych na stronie Głównego Urzędu Statystycznego (GUS) na terenie powiatu sokólskiego działa 11 obiektów 
noclegowych, posiadających razem 287 miejsc. W tym na terenie gminy Sokółka znajduje się 7 obiektów noclegowych, na terenie gminy Dąbrowa Białostocka 1 obiekt noclegowy oraz 2 obiekty na terenie gminy Suchowola (Bank Danych Lokalnych, 2020). Po sprawdzeniu źródeł, takich jak Google Maps (2020), OpenStreetMap.org (2020) oraz Noclegi.pl (2020), wysnuto wniosek, że na badanym obszarze znajduje się w sumie 17 obiektów (czyli o 6 więcej niż ujęto w danych GUS). Na terenie powiatu najpopularniejszą formą udostępniania miejsc noclegowych są obiekty agroturystyczne oraz kwatery prywatne (wynajem pokoi). Według dostępnych danych funkcjonuje tam 35 kwater prywatnych oferujących noclegi (Noclegi.pl, 2020). Na obszarze powiatu znajduje się dodatkowo kilka obiektów zrzeszonych w Podlaskim Stowarzyszeniu Agroturystycznym.

Dla turystów rowerowych najlepiej przystosowanymi obiektami noclegowymi na terenie powiatu są gospodarstwa agroturystyczne. Wiele z nich posiada miejsca, w których turysta może zostawić swój rower oraz ma w ofercie podstawowe narzędzia naprawcze. Właściciele takich obiektów są również źródłem wiedzy na temat atrakcji turystycznych $\mathrm{w}$ regionie, co jest przydatne, biorąc pod uwagę małą liczbę przewodników czy map, które powinny zawierać podstawowe informacje. Na terenie powiatu można również skorzystać z campingów, umożliwiających nocleg w namiotach, przyczepach turystycznych oraz kamperach.

W Sokółce znajduje się szesnaście dużych obiektów gastronomicznych, takich jak pizzeria Savona, Karczma Pod Sokołem czy Restauracja Zacisze. W Dąbrowie Białostockiej działa siedem obiektów gastronomicznych. Do największych należą Sala Bankietowa "Sympatia” oraz „Zajazd na Skarpie" oferujący również usługi noclegowe. Na terenie Suchowoli obiektem z największą ofertą gastronomiczną jest restauracja w pensjonacie „Poniatowski". Oferuje ona organizację imprez okolicznościowych, catering oraz dania kuchni polskiej.

Na terenie miasta Sokółka znajdują się dwa sklepy rowerowe. Sklep rowerowy "Lider-Serwis, Rowery”, który pełni jednocześnie funkcję warsztatu rowerowego i wypożyczalni oraz sklep sportowy położony na ulicy 1 Maja (OpenStreetMap.org, 2020). W sezonie letnim turyści mogą wypożyczyć rowery w Polskim Domu Rodzinnym Serce, znajdującym się w Sokółce na ul. Kryńskiej (Wiśniewska, Pluta, Wiśniewski, Nowakowska, 2018).

W miejscowości Krynki oraz Korycin nie ma żadnej wypożyczalni ani serwisu rowerowego. W Suchowoli, na placu Kościuszki, dzia- 
ła sklep rowerowy Elpiro. Warto zaznaczyć, że niektóre obiekty agroturystyczne oferują swoim gościom nieodpłatne wypożyczenie rowerów.

Przy trasach rowerowych, którymi można dotrzeć do atrakcji powiatu sokólskiego, nie ma miejsc specjalnie przeznaczonych na odpoczynek, choć trasy wiodą przez mało ruchliwe drogi oraz lasy, a więc są warunki do utworzenia takich punktów. Turyści szukają wytchnienia w mijanych wsiach i miasteczkach oraz działających w nich obiektach turystycznych. Niestety, przy takich miejscach nie ma odpowiedniej infrastruktury technicznej, z której rowerzyści mogliby skorzystać w razie awarii roweru. Tego rodzaju wyposażenie powinno znajdować się przy profesjonalnie wykonanych miejscach wypoczynku położonych na terenie powiatu.

W Suchowoli, Sokółce, Dąbrowie Białostockiej oraz Szudziałowie znajdują się centra informacji turystycznej, których pracownicy dostarczają zwiedzającym niezbędnych informacji, dotyczących atrakcji turystycznych czy przebiegu wybranych szlaków. W każdym z tych obiektów dostępne są również bezpłatne mapy i foldery, z których turyści mogą skorzystać. Usługi transportowe na terenie powiatu sokólskiego nie są wysoko rozwinięte. Do miejscowości znanych z historii Tatarów: Bohonik oraz Kruszynian nie da się dojechać pociągiem. W sezonie letnim czasem kursują tam autobusy, jednak najlepszy dojazd zagwarantuje turyście własny środek transportu. Do każdej z miejscowości można dojechać rowerem. Do Suchowoli, Sokółki, Dąbrowy Białostockiej, Bohonik oraz Kruszynian prowadzą szlaki rowerowe. Ich trasy przebiegają głównie drogami o niskiej częstotliwości ruchu.

W wyniku przeprowadzonego rekonesansu terenowego, stwierdzono, że wiele tras opisanych w przewodnikach czy folderach dostępnych w informacjach turystycznych nie jest oznakowanych w terenie. Powoduje to duże problemy przy poruszaniu się rowerem, szczególnie dla turystów podróżujących bez mapy czy nawigacji GPS.

\section{Szlaki rowerowe}

Według informacji, dostępnych na stronach gmin oraz zebranych podczas rekonesansu terenowego, na obszarze powiatu sokólskiego znajduje się 17 tras rowerowych o łącznej długości $591 \mathrm{~km}$. Biorąc pod uwagę, że powierzchnia powiatu to $2055 \mathrm{~km}^{2}$, można obliczyć, że gęstość tras wynosi $28,7 \mathrm{~km} / 100 \mathrm{~km}^{2}$. 


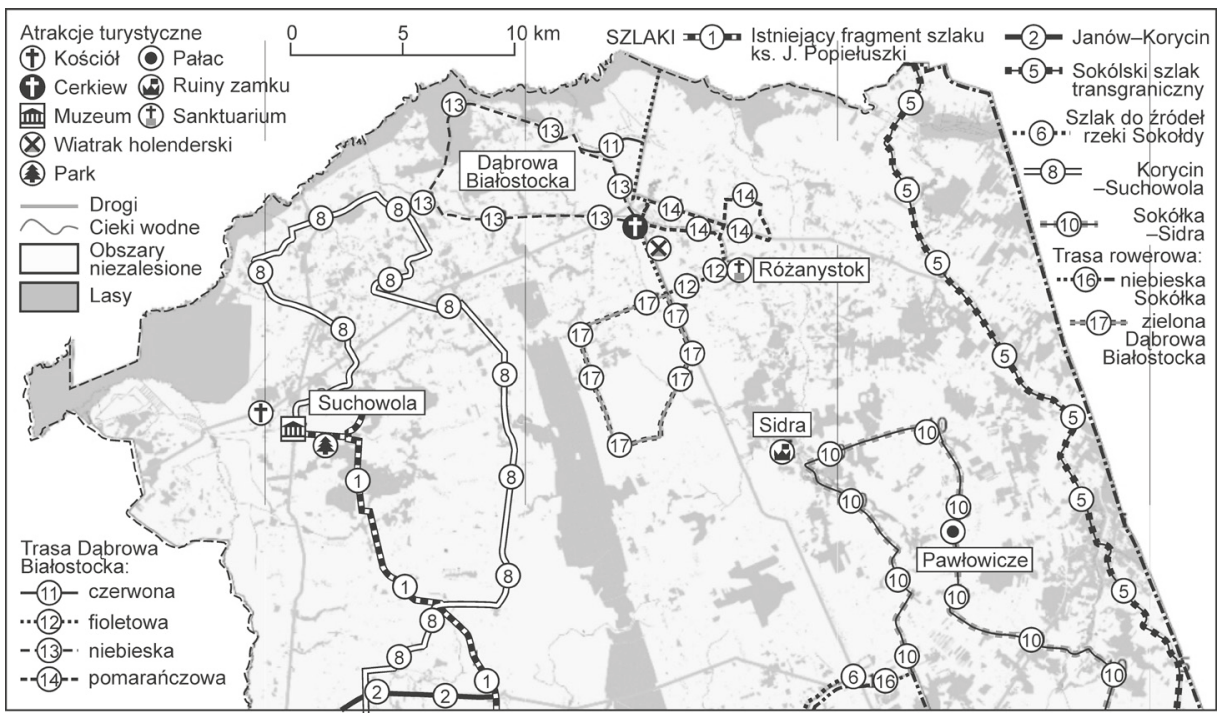

Rysunek 2. Szlaki rowerowe i atrakcje turystyczne w północnej części powiatu sokólskiego Źródło: opracowanie własne

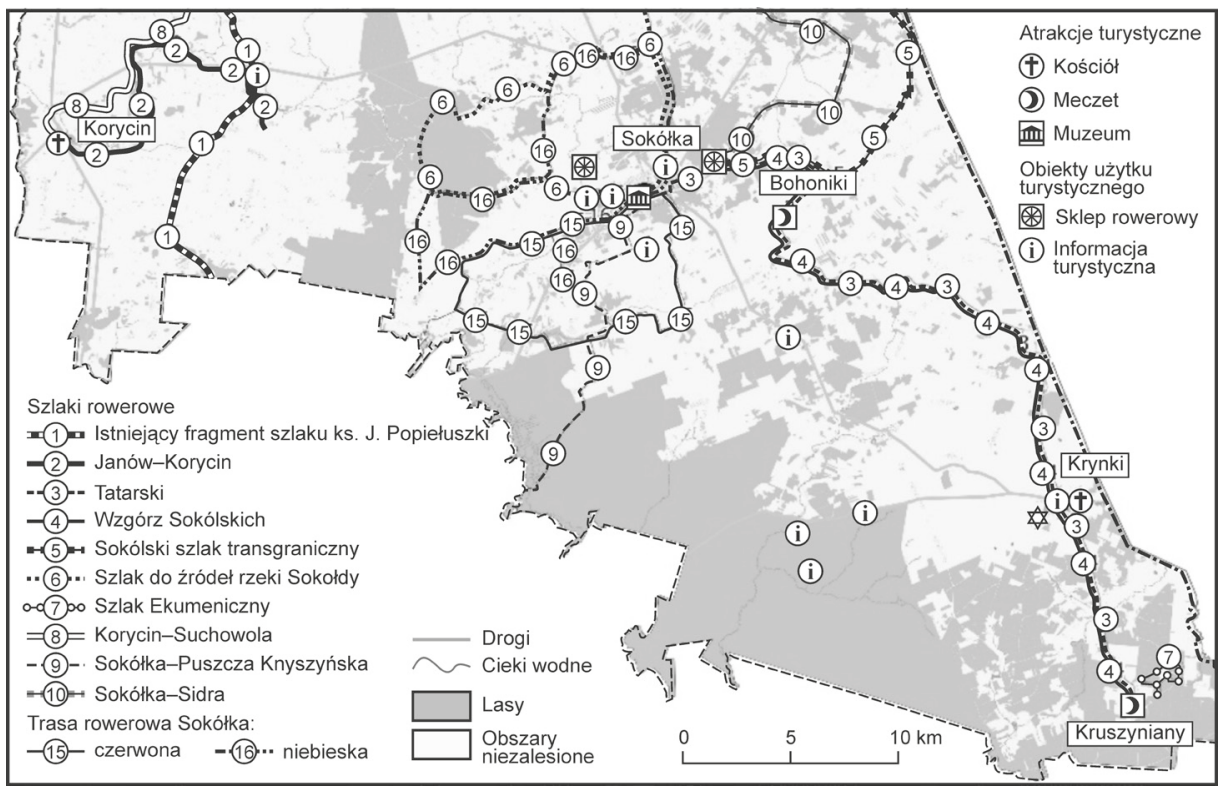

Rysunek 3. Szlaki rowerowe i atrakcje turystyczne w południowej części powiatu sokólskiego Źródło: opracowanie własne 
Szlaki rozpoczynają się w trzech głównych miastach powiatu: Suchowoli, Dąbrowie Białostockiej oraz Sokółce. Na potrzeby pracy stworzono mapę powiatu, którą podzielono na część północną (rys. 2) oraz południową (rys. 3). Na obu umieszczono szlaki rowerowe powiatu sokólskiego. Przy tworzeniu mapy wykorzystano informacje znajdujące się na stronach internetowych gmin: Sokółka, Suchowola oraz Dąbrowa Białostocka.

Najdłuższym szlakiem przebiegającym w całości przez powiat sokólski jest Szlak Rowerowy Korycin-Suchowola o długości 62 km. Trasa zaczyna się w miejscowości Korycin, znanej z wytwarzania lokalnego sera korycińskiego oraz święta truskawki. Szlak kończy się w jednym z większych miast powiatu sokólskiego - Suchowoli. Przez teren powiatu przebiega również Sokólski szlak transgraniczny, którego długość wynosi $83 \mathrm{~km}$. Trasa zaczyna się w Sokółce i wiedzie wzdłuż granicy polsko-białoruskiej. Na terenie powiatu sokólskiego długość trasy wynosi $51 \mathrm{~km}$, a pozostałe $32 \mathrm{~km}$ są wytyczone przez powiat augustowski. Najkrótszym szlakiem na badanym obszarze jest szlak Ekumeniczny o długości $6 \mathrm{~km}$, przebiega on wokół zalewu Ozierany. Największe zagęszczenie szlaków występuje w miejscowości Sokółka, gdzie początek ma 8 szlaków rowerowych - znajdują się głównie w północnej i środkowej części powiatu. Na badanym obszarze występują ponadto trzy szlaki tematyczne. Rowerowy Szlak Tatarski o długości $48 \mathrm{~km}$ przebiega przez miejscowości związane z ludem Tatarskim na Podlasiu. Na trasie znajdują się takie obiekty, jak meczety w Kruszynianach i Bohonikach wpisane na listę Pomników Historii czy Muzeum Ziemi Sokólskiej, w którym możemy zobaczyć tradycyjne stroje tatarskie. Szlak Rowerowy im. bł. ks. Jerzego Popiełuszki prowadzi przez obszary związane z życiem duchownego. Do takich miejsc należy Suchowola, gdzie znajduje się pomnik ks. Popiełuszki oraz szkoła i kościół, do których uczęszczał. Przygotowana trasa przebiega również przez wieś Okopy, w której urodził się Jerzy Popiełuszko. Najkrótszym szlakiem tematycznym jest Szlak Ekumeniczny, utworzony aby przybliżyć turystom historię terenów, po których wędrują.

Szlaki rowerowe łączą najważniejsze zabytki położone w powiecie sokólskim. Prowadzą przez tereny o małym ruchu ulicznym. Na obszarach, przez które przebiegają szlaki rowerowe, można zauważyć brak specjalnie przygotowanych miejsc do odpoczynku dla rowerzystów. Punkty takie są zdecydowanie niezbędne przy trasach prowadzących drogami, na których nie ma miejsc, aby odstawić rower czy spożyć posiłek. Szlaki nie są również oznaczone w sposób czytelny w terenie. Na 
skrzyżowaniach dróg nie ma drogowskazów. Powiat posiada duże możliwości rozwoju turystyki rowerowej, jednak brak mu niezbędnej infrastruktury.

\section{Analiza SWOT powiatu sokólskiego pod względem turystyki rowerowej}

Powiat sokólski posiada wiele zalet, wśród których najważniejsze to walory kulturowe oraz położenie. Badany powiat jest położony na obszarze, gdzie występuje czyste powietrze i mnóstwo terenów zielonych, a ponadto znajduje się w strefie przygranicznej, co daje wiele możliwości rozwoju. Stwierdzono, że największą zaletą obszaru są walory kulturowe - powiat jest związany z historią trzech religii: żydowskiej, tatarskiej oraz chrześcijańskiej.

Słabe strony powiatu związane są głównie z brakiem promocji turystyki oraz sposobem oznaczania istniejących szlaków rowerowych zarówno na mapie, jak i w terenie. Omawiany powiat oraz jego walory nie są częstym przedmiotem zainteresowania turysty między innymi ze względu na słabą promocję tego terenu. Pomimo wielu możliwości rozwoju turystyki rowerowej, szlaki w powiecie nie są dostosowane do użytku przez turystów rowerowych. Największym utrudnieniem dla zwiedzających są: regionalne oznaczenia tras, brak niezbędnej infrastruktury na trasach oraz brak mapy przedstawiającej przebieg szlaków rowerowych na badanym obszarze.

W analizie SWOT wśród szans zaproponowano dla powiatu kilka możliwości rozwoju turystyki. Niektóre z nich wiążą się z utworzeniem nowych szlaków rowerowych, inne z organizacją wydarzeń promujących turystykę rowerową oraz badany obszar. Na tym etapie analizy zwrócono również uwagę na możliwość pozyskania zewnętrznych środków finansowych, pomocnych przy promocji powiatu i rozbudowaniu sieci szlaków rowerowych. Zwrócono również uwagę na zewnętrzne zalety położenia powiatu, takie jak sąsiedztwo z Kanałem Augustowskim, który jest rozpoznawalnym miejscem, często odwiedzanym przez turystów.

Zagrożenia $\mathrm{w}$ rozwoju infrastruktury rowerowej są związane z możliwym brakiem napływu turystów. Wynika to między innymi ze zwiększonego zainteresowania turystyką zagraniczną i jej coraz większą dostępnością. Turystyka zagraniczna staje się coraz bardziej popularna i osiągalna, przez co Polacy częściej mogą wykazywać zainteresowanie zwiedzaniem innych krajów Europy, odpowiednio przygotowanych na przyjęcie rowerzystów. 


\section{Propozycje zmian $w$ infrastrukturze rowerowej}

W celu zwiększenia liczby turystów na badanym obszarze oraz spopularyzowania go pod względem turystyki rowerowej zaproponowano kilka zmian. Można wśród nich wyróżnić działania niewymagające czasu realizacji dłuższego niż rok oraz takie, których wprowadzenie może zająć więcej niż 12 miesięcy.

Badany obszar posiada wiele szlaków rowerowych, biegnących przez drogi wiejskie czy lasy, gdzie nie ma specjalnych miejsc na odpoczynek dla rowerzystów. Warto na takich trasach przygotować stanice rowerowe bądź inne punkty umożliwiające odpoczynek, dopasowane do potrzeb turystów. Powinny one być specjalnie oznakowane oraz mieć np. drewnianą ławkę i stolik. Dodatkowo warto wyposażyć wyżej wymienione miejsca $\mathrm{w}$ stojaki na rowery, stacje naprawcze z podstawowym sprzętem rowerowym, a co najważniejsze tabliczki informacyjne. Na tabliczkach powinien znajdować się dokładny opis szlaku wraz z mapą i zaznaczonym miejscem, gdzie aktualnie jesteśmy. Jeśli trasa prowadzi przez miejsca atrakcyjne przyrodniczo warto postawić na niej tabliczki edukacyjne z opisem fauny i flory odwiedzanego miejsca. Zaproponowano lokalizację 22 miejsc odpoczynku dla turystów (rys. 4), które wybrano na podstawie długości i przebiegu danego szlaku rowerowego. Na dłuższych szlakach, ponad $40 \mathrm{~km}$, umiejscowione zostały co najmniej 2 miejsca odpoczynku. W sumie zasugerowano położenie 22 miejsc odpoczynku, z czego 17 znajduje się na terenach leśnych, a 4 są zlokalizowane w miejscu połączeń dwóch różnych tras rowerowych. Przy lokalizacji punktu odpoczynku brano również pod uwagę odległość od najbliższego miasta czy wsi, ponieważ uznano, że ważne jest, aby turyści mieli możliwość zakupu podstawowych artykułów spożywczych kilka minut przed dotarciem do miejsca odpoczynku.

Wiele szlaków rowerowych w powiecie sokólskim znajduje się w niedalekiej odległości od siebie, dlatego stwierdzono, że ciekawą możliwością jest połączenie niektórych szlaków rowerowych (rys. 4). Dzięki temu kilka szlaków zostało wydłużonych, a turyści rowerowi mają większe możliwości dopasowania tras do swoich potrzeb i wymagań.

Z przeprowadzonego rekonesansu terenowego wynika, że trasy rowerowe $w$ powiecie często nie posiadają oznakowania $w$ terenie. Warto je wprowadzić, ponieważ znacznie ułatwi to turystom poruszanie się po tym obszarze. Dobrym pomysłem byłoby wprowadzenie znaków stosowanych przez Polskie Towarzystwo Turystyczno-Krajoznawcze. Na skrzyżowaniach szlaków rowerowych warto umieścić drogowskazy, wraz z informacją ile kilometrów zostało do końca trasy. 


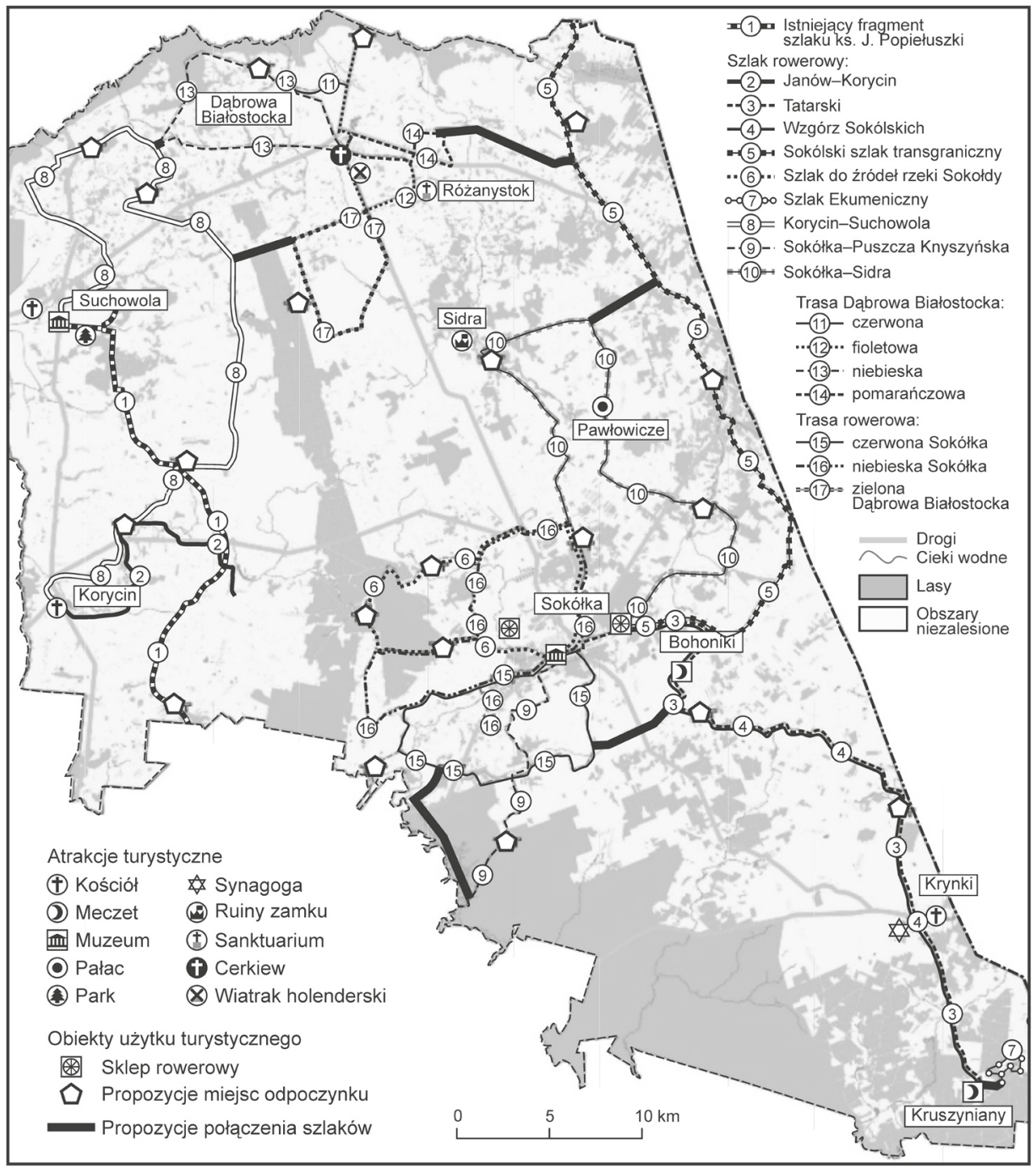

Rysunek 4. Propozycje lokalizacji miejsc odpoczynków oraz połączenia szlaków w powiecie sokólskim Źródło: opracowanie własne

Turystyka rowerowa powinna być również bardziej popularyzowana na terenie powiatu. Warto w szkołach podstawowych przeprowadzać akcje promujące ten rodzaj aktywności, zajęcia czy warsztaty o tematyce rowerowej mogą być przeprowadzane na przykład przez policję lub nauczycieli wychowania fizycznego. W ramach zajęć pozaszkolnych można również organizować wycieczki rowerowe dla chętnych 
uczniów. W celu popularyzacji tego rodzaju turystki należy przeprowadzać akcje mające na celu dotarcie również do starszych grup społecznych. W wielu miastach akcje takie noszą nazwę: "Zamień auto na rower" czy „Dzień bez samochodu” i zyskują coraz większą popularność na terenie Polski.

Ciekawą formą promocji mogą być także artykuły zamieszczane w czasopismach branżowych, takich jak Rowertour czy Bikeboard, ponieważ trafiają one do sprecyzowanej grupy adresatów, w tym wypadku osób uprawiających turystykę rowerową. Publikacje mogą stać się dla czytelników inspiracją do przygotowania i zrealizowania wyprawy rowerowej na badanym terenie.

W obiektach noclegowych warto dopasować ofertę do potrzeb turystyki rowerowej. $W$ ramach promocji obiektu można zaproponować usługe C\&B (Cycle \& Breakfest), która oprócz ceny noclegu obejmuje również miejsce na przechowanie roweru czy dostęp do podstawowych narzędzi naprawczych.

W kwestii obiektów noclegowych można stworzyć więcej campingów dostosowanych do użytku przez podróżników dysponujących kamperem czy przyczepą campingową. Mogą one służyć jako krótkie noclegi tranzytowe na trasie z Polski do Europy Wschodniej. Turyści korzystający z tego typu noclegu chętnie poznają najbliższą okolicę i spróbują regionalnych potraw. Swoim doświadczeniem podzielą się z innymi miłośnikami karawaningu i poprzez tzw. marketing szeptany przyczynią się do popularyzacji regionu.

Aby turystyka rowerowa rozwijała się na terenie powiatu, niezbędną rzecza, oprócz szlaków rowerowych, są rowery. Nie każdy może kupić rower lub zabrać go na wakacje, dlatego warto utworzyć wypożyczalnie rowerowe. Coraz większą popularność zyskują również rowery publiczne. Wypożyczyć je może każdy mieszkaniec, posiadający odpowiednią aplikację $\mathrm{w}$ telefonie. Jest to bardzo dobre rozwiązanie, jeśli chodzi o popularyzację turystyki rowerowej.

Powiat sokólski wyróżnia się dużą ilością terenów zielonych i lasów, co sprzyja rozwojowi turystyki rowerowej z udziałem rowerów MTB, które są przeznaczone do jazdy w trudnym terenie, np. po trasach górskich czy leśnych szlakach. Władze powiatu mogłyby organizować wyścigi MTB czy różnego rodzaju wydarzenia, takie jak festiwale rowerowe. Przyczyniłoby się to do wzrostu znaczenia regionu w turystyce oraz promocji obszaru.

Na terenie powiatu sokólskiego w 2019 r. wytyczony był jeden rowerowy szlak transgraniczny - prowadzący wzdłuż granicy z Białorusia, ale w żadnym momencie jej nie przekraczający. Warto zmienić bieg szlaku 
lub dodać do niego alternatywny fragment, który prowadziłby do miejscowości Grodno. Jest to jedno z większych miast znajdujących się na terenie Białorusi, posiadające ciekawą historię i zabytki związane również $\mathrm{z}$ historią Polski. Przekroczenie granicy dla turystów z Polski nie powinno stanowić problemu, ponieważ na terenie miasta Grodno obowiązuje ruch bezwizowy (Dekret, 2019).

Innym pomysłem, mogącym pomóc w rozwoju powiatu sokólskiego, jest stworzenie szlaku rowerowego Suchowola-Augustów. Długość trasy w jedną stronę wynosi około $42 \mathrm{~km}$. Kanał Augustowski przyciąga rzesze turystów, również z zagranicy, a istnienie takiego szlaku rowerowego i jego odpowiednia promocja przyczyniłyby się do popularyzacji Suchowoli i jej okolic. Turyści po dodarciu do kanału mogliby udać się w rejs statkiem i zobaczyć działanie śluz. Taka podróż rowerem i wycieczka statkiem zajmują cały dzień, więc warto wprowadzić również ułatwienia komunikacyjne dla turystów rowerowych.

Można uruchomić linie pociągowe kursujące z Suchowoli do Augustowa oraz z Sokółki do Białegostoku. Pociaggi takie powinny być wyposażone $\mathrm{w}$ wagony przystosowane do przewozu rowerów. Dzięki takiemu rozwiązaniu turyści mogą poświęcić więcej czasu na zwiedzanie danego miejsca, ponieważ w jedną stronę mogą jechać rowerem, a z powrotem pociągiem. Warto również dostosować komunikację publiczną na terenie powiatu sokólskiego do przewozu rowerów. Autobusy mogłyby zostać wyposażone w przyczepy rowerowe lub posiadać wewnątrz miejsce na więcej niż 2 rowery.

Dobrą inwestycją byłoby również zaprojektowanie szlaków rowerowych dla rodzin $\mathrm{z}$ dziećmi. W powiecie sokólskim nie ma szlaków dostosowanych do tej grupy odbiorców. Trasa taka powinna być poprowadzona po ścieżce leśnej lub drodze dla rowerów, najlepiej z dala od ruchliwych ulic. Ważne jest, aby taka trasa nie była monotonna oraz posiadała infrastrukturę rowerową - przygotowane miejsca odpoczynku, z miejscem do siedzenia oraz tabliczki informacyjno-edukacyjne. Trasa powinna również być w sposób czytelny przedstawiona na mapie oraz wyraźnie oznakowana w terenie.

\section{Wnioski}

W toku pracy stwierdzono znaczny niedobór wydawnictw kartograficznych oraz źródeł informacji o trasach rowerowych w powiecie sokólskim. Brakuje mapy uwzględniającej wszystkie opisane przez autorkę trasy. 
Przewodniki i foldery dostępne dla turystów najczęściej mają charakter poglądowy, mimo że trasa była na nich zaznaczona, jej przebieg nie był opisany, co stanowiło duży problem podczas analizy. Zaobserwowano również, że trasy nie posiadają żadnej infrastruktury rowerowej, a informacje na temat ich przebiegu są trudno dostępne.

W toku pracy stwierdzono, że teren powiatu nie posiada podstawowej infrastruktury rowerowej. Zaobserwowano, że najczęściej występującą bazą noclegową na badanym obszarze są kwatery prywatne oraz gospodarstwa agroturystyczne. Niektóre z nich oferują miejsce do przechowania roweru.

Podczas zbierania informacji dowiedziano się o planowanej rozbudowie szlaku rowerowego im. bł. ks. Popiełuszki. Ma on przebiegać przez wszystkie miejscowości w powiecie, związane z życiem księdza oraz posiadać specjalnie przygotowane miejsca do odpoczynku oraz tablice informujące, gdzie turysta znajduje się w danym momencie wycieczki.

$\mathrm{Na}$ terenie powiatu nie ma tras rowerowych przystosowanych do turystyki rodzin z dziećmi. Szlaki często prowadzą do atrakcji turystycznych, które nie są gotowe na przyjęcie rowerzystów oraz nie posiadają miejsc na bezpieczne zostawienie roweru.

Na szlakach uczęszczanych przez turystów rowerowych nie ma specjalnie przygotowanych miejsc do odpoczynku, stanowisk naprawczych czy tablic informacyjnych. Szlaki są również bardzo słabo oznakowane. Na rozwidleniach dróg nie ma drogowskazów.

Wnikliwa analiza SWOT oraz zebranych dokumentów pokazała, że obszar powiatu może stać się atrakcyjny dla turystyki rowerowej. Atutami gminy Sokółka są: bogata historia, obiekty związane z ludnością tatarską oraz usytuowanie na terenie Zielonych Płuc Polski. Przygraniczne położenie i sąsiedztwo Kanału Augustowskiego również wpływają pozytywnie na potencjał turystyczny powiatu. Najważniejsze to skuteczna promocja turystyki rowerowej, rzetelne przygotowanie dostępnych już tras rowerowych oraz przemyślany marketing. Ważne jest, aby promocja odbywała się na terenie całego powiatu.

Analiza SWOT stała się punktem wyjścia do opracowania propozycji zmian w zagospodarowaniu powiatu dla turystyki rowerowej. Zaproponowano siedem zmian, których wykonanie nie wiąże się z dużymi kosztami dla powiatu, a wspomoże rozwój turystyki rowerowej na badanym obszarze. Przedstawiono również pięć zmian z dłuższym okresem realizacji. Jedną z ważniejszych jest opracowanie mapy tras rowerowych całego powiatu wraz z informacjami na temat obiektów noclegowych, wypożyczalni i sklepów rowerowych. Stwierdzono również 
potrzebę budowy szlaku rowerowego dla rodzin z dziećmi oraz dodanie fragmentu zagranicznego do transgranicznej trasy rowerowej.

Z przeprowadzonej analizy wynika, że powiat sokólski posiada cechy, które mogą spowodować, że w przyszłości stanie się interesującym kierunkiem dla turystów rowerowych. Aby jednak tak się stało, należy promować turystykę rowerową na tym obszarze oraz stworzyć niezbędną infrastrukturę.

\title{
Bibliografia
}

Bank Danych Lokalnych (2020). Pobrane z: https://bdl.stat.gov.pl/BDL/dane/teryt/tablica (10.05.2020).

Dekret Prezydenta Republiki Białorusi z dn. 07.08.2019 r. o ustanowieniu bezwizowej procedury wjazdu i wyjazdu cudzoziemców, nr 300.

Google Maps (2020). Pobrane z: https://www.google.pl/maps/preview (12.04.2020).

Noclegi.pl (2020). Pobrane z: https://noclegi.pl/sokolka (27.05.2020).

Nowacki, M., Tanaś, S. (red.) (2012). Turystyka rowerowa w Zjednoczonej Europie. Warszawa: Polskie Towarzystwo Turystyczno-Krajoznawcze.

OpenStreetMap.org (2020). Pobrane z: https://www.openstreetmap.org/\#map=19/ $53.40417 / 23.49605$ (10.04.2020).

Ostrowska, A. (2020). Zielone Płuca Polski-cząstka kraju, do której zawsze wracamy. Pobrane z: https://swiatrolnika.info/zielone-pluca-polski_(10.04.2020).

Rybicki, J. (2015). Po Bajkale. Warszawa: Wydawnictwo Świat Książki.

Serwis Informacyjny Powiatu Sokólskiego (2020). Pobrane z: http://sokolka-powiat.pl (10.05.2020).

Sokółka.pl (2020). Pobrane z: http://sokolka.home.pl (10.05.2020).

Wiśniewska, E., Pluta, A., Wiśniewski, E., Nowakowska, S. (2018). Sokólszczyzna - mini-przewodnik. Sokółka: Podlaskie Stowarzyszenie Agroturystyczne.

\section{ZAGOSPODAROWANIE POWIATU SOKÓLSKIEGO DLA TURYSTYKI ROWEROWEJ}

\begin{abstract}
Abstrakt: Celem artykułu jest zaproponowanie zmian, jakie można wprowadzić w zagospodarowaniu powiatu sokólskiego, aby ulepszyć warunki uprawiania turystyki rowerowej. Dane niezbędne do opracowania zbierano na przełomie 2019 i 2020 r. Przeprowadzono rekonesans terenowy, przeanalizowano zebrane materiały oraz informacje znalezione na stronach internetowych gmin i powiatu. Przygotowano analizę SWOT dla turystyki rowerowej. W ramach pracy stworzono kilka map w programie QGIS, na których umieszczono atrakcje turystyczne w powiecie oraz trasy rowerowe. Na podstawie uzyskanych informacji zaproponowano kilka zmian, dzięki którym badany obszar byłby miejscem interesującym dla turystów rowerowych. Opracowano również mapę potencjalnych miejsc odpoczynku dla rowerzystów i zaproponowano kilka rozwiązań mających na celu polepszenie promocji turystyki w powiecie sokólskim.
\end{abstract}

Słowa kluczowe: turystyka rowerowa, powiat sokólski, infrastruktura rowerowa, szlaki rowerowe, Sokółka. 


\section{DEVELOPMENT OF THE SOKÓŁKA DISTRICT FOR BICYCLE TOURISM}

Abstract: The purpose of the article is to propose changes in the development of the Sokółka district for bicycle tourism based on data obtained at the beginning of 2020. A field reconnaissance was carried out, and the materials collected and information found on the poviat's websites were analyzed. A SWOT analysis was prepared in terms of bicycle tourism and, as part of the work, several maps were created through the QGIS program showing both tourist attractions in the Sokółka district and bicycle routes. On the basis of the information obtained, several changes were proposed in order to create places of interest for bicycle tourists in the studied area. A map of potential stopping points for cyclists was also produced and several ideas were proposed to improve the promotion of the area.

Keywords: bicycle tourism, Sokółka district, bicycle infrastructure, bike trails, Sokółka. 